lic Service, University of Virginia, were honored by the APSA Committee on the Status of Blacks in the Profession at the annual meeting at the Washington Hilton. Both Puryear and Adams were the first two chairs of the committee when it was formed in 1969. They were recognized for their scholarship, leadership and mentorship. Matthew Holden, University of Virginia, and Michael Frazier, Howard University, discussed some of the many contributions of the two scholars.

Mitchell Rice, Louisiana State, chair of the Committee, made the presentations at the annual nightcap reception of the Committee.

\section{Herring Honored for Print Collection}

Pendleton Herring, president of the Association in 1952-53, was honored at a reception during the annual meeting for his generosity in donating to the Association over many years an impressive collection of political prints.

President Lowi presided at the ceremony where Herring presented the Association yet another print, "Canvassing for a Vote" by Bingham and the Association presented to Herring a plaque and a copy of the Hogarth print of "The Politician."

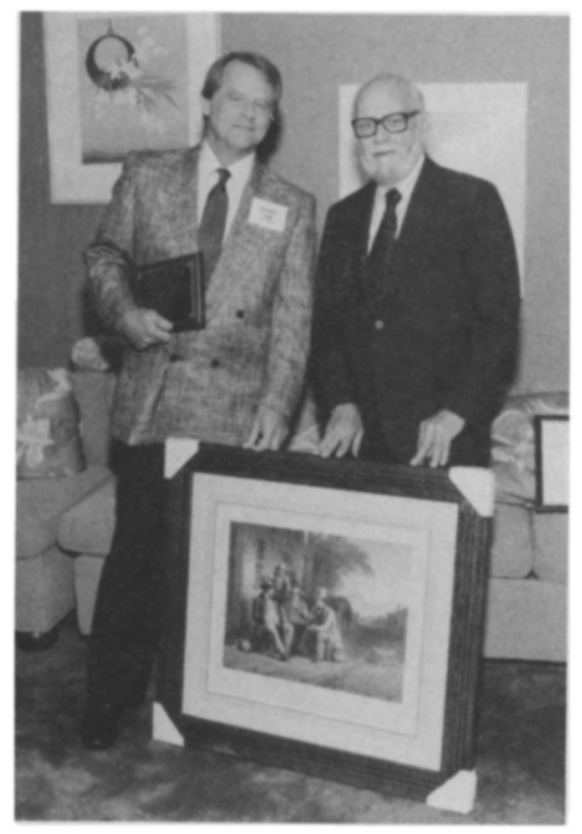

Theodore Lowi Accepts Print from Pendleton Herring.
The Pendleton Herring Print Collection, "Political Institutions and Behavior as Represented in Art," now contains about 50 pieces.

\section{New APSA Officers Elected}

APSA President Theodore J. Lowi presided at the Association's 1991 annual business meeting August 31, Washington, D.C., where new officers were elected.

Lucius J. Barker was elected president-elect; he will assume the office of the president in 1992-93. Elected to one-year terms as vice presidents are M. Margaret Conway, University of Florida; Wilson Carey McWilliams, Rutgers University; and Jane J. Mansbridge, Northwestern University.

Elected to a two-year term as Treasurer is James J. Caporaso, University of Washington, and to a oneyear term as secretary is Leon $\mathbf{N}$. Lindberg, University of Washington. Eight new Council members were also elected for two-year terms: Susan C. Bourque, Smith College; Germaine A. Hoston, Johns Hopkins University; Richard W. Mansbach, Iowa State University; Gwendolyn Mink, University of California, Santa Cruz; Ronald Rogowski, University of California, Los Angeles; Nancy L. Rosenblum, Brown University; Martin Shefter, Cornell University; and Hanes Walton, Jr., Savannah

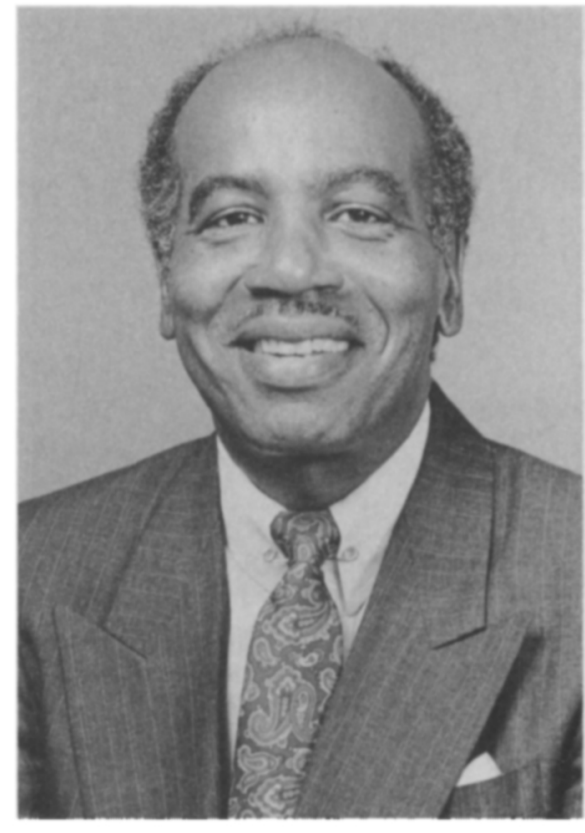

Lucius J. Barker

State College.

At the end of the meeting Lowi passed the gavel to James Q. Wilson to begin his term as president. Wilson has selected Jean Bethke Elshtain, Virginia Gray, Ronald Rogowski and Martin Shefter to join himself, Lucius Barker and James Caporaso on the Association's Administrative Committee.

Editor's Note: A list of all Association committees and their membership will appear in the March issue of $P S$.

\title{
Travel Grants for Foreign Scholars Attending Annual Meeting
}

Forty-nine foreign scholars and graduate students were the recipients of travel grants to attend the 1991 APSA Annual Meeting in Washington, D.C. Foreign graduate students attending U.S. universities were selected competitively and received travel money made available by the Huang Hsing Foundation, the Asia Foundation, and the APSA Council. More senior foreign scholars who had been invited to present papers at the Annual Meeting were also awarded travel funds by the APSA Council.

As part of an exchange between the APSA and the Japan Political Science Association, three Japanese political scientists attended the Annual Meeting and presented papers at a panel on Party, Electorate and Labor Policy in Japan Today, chaired by George $O$. Totten. The exchange program is supported by a grant to the APSA from the Japan-U.S. Friendship Commission, and is now in its second year of operation.

A list of the foreign grantees and their affiliations follows. 
International Grantees at Annual Meeting

Name
HUANG HSING FOUNDA
Feng Chen
Ting Gong
Dali Yang
Carl K. Y. Shaw
ASIA FOUNDATION (21)
Subrata Dhar
Rolin Mainuddin
Andrew Mak
Junko Kato
Kyiung-Ho Cho
Young-Bae Hwang
Ho-Won Jeong
Seong-Ho Joo
Ku-Pyo Lee
Seonghwa Lee
Mahnaz Fatima
Rashila Ramli
Weixing Chen
Ming Gao
Xiaoming Huang
Siang-giang Jian
Guoli Liu
Yu Lu
Li-Khan Chen
Chien-chung Yin
Rangsima Sirirangsi

U.S. Affiliation

Country

ON (4)

Syracuse

Syracuse

Princeton

Iowa

PRC

PRC

PRC

Taiwan

Hawaii

Kansas

Texas A\&M

Yale

Georgia

Vanderbilt

Ohio State

Penn State

Illinois

Purdue

N. Illinois

N. Arizona

N. Illinois

Washington

USC

Kent State

SUNY-Buffalo

SUNY-Stony Brook

N. Texas

UCLA

N. Texas

APSA COUNCIL GRANTS (12)

$\begin{array}{ll}\text { Itty Abraham } & \text { Illinois } \\ \text { Majeb Alhamwi } & \text { USC } \\ \text { Napoleon Bamfo } & \text { Georgia } \\ \text { Ali Carkoglu } & \text { SUNY-Binghamton } \\ \text { Diya Dutt } & \text { Cincinnati } \\ \text { Rachel K. Gibson } & \text { Texas A\&M } \\ \text { Christoph Hanterman } & \text { UC, Santa Barbara } \\ \text { Arie Kacowicz } & \text { Princeton } \\ \text { Christopher Kirkey } & \text { Brandeis } \\ \text { James R. Sellars } & \text { Wayne State } \\ \text { Lars Skalnes } & \text { UCLA } \\ \text { Stewart Wood } & \text { Harvard }\end{array}$

SENIOR SCHOLARS GRANTS-APSA COUNCIL

Zahoor Ahmed Awan

Clark Atlanta

Martin Bull

Weixing Guo

Thomas Poguntke

Birgit Sauer

J. J. Seiler

Thierry Vedel

University of Salford

Harvard-Yenching

Universität Mannheim

Frei Universität Berlin

UNIBO-South Africa

CEVIPOF, Fondation Nationale

\section{Participation by Women in the 1991 APSA Meeting}

\author{
Martin Gruberg \\ University of Wisconsin-Oshkosh
}

This is the twentieth year that I
Bangladesh

Bangladesh

Hong Kong

Japan

Korea

Korea

Korea

Korea

Korea

Korea

Pakistan

Malaysia

PRC

PRC

PRC

PRC

PRC

PRC

Taiwan

Taiwan

Thailand

India

Syria

Ghana

Turkey

India

Britain

Germany

Israel

Canada

Canada

Norway

Britain

Pakistan

Britain

PRC

Germany

Germany

South Africa

France
APSA-JPSA EXCHANGE PROGRAM-VISITING JAPANESE SCHOLARS Junnosuke Masumi, The Woodrow Wilson Center

Sadafumi Kawato, Hokkaido University

Ikuo Kume, Kobe University have reported in $P S$ on the sex participation balance at our meetings. Truly we've come a long way.

\begin{tabular}{lcrr} 
Year & Total & Women & $\%$ \\
& \multicolumn{2}{c}{ Chairpersons } \\
$1961^{\mathrm{a}}$ & 51 & 0 & \\
$1971^{\mathrm{b}}$ & 154 & 12 & 0.0 \\
$1981^{\mathrm{c}}$ & 137 & 16 & 7.8 \\
$1990^{\text {d }}$ & 487 & 106 & 21.8 \\
$1991^{\mathrm{n}}$ & 439 & 107 & 24.4
\end{tabular}

1961

1971

1981

1990

1991

\section{Paper Givers}

$\begin{array}{rrr}85 & 2 & 2.4 \\ 552 & 43 & 7.8 \\ 520 & 98 & 18.8 \\ 2071 & 490 & 23.7 \\ 1940 & 512 & 26.4\end{array}$

1961

1971

1981

1990

1991

\section{Discussants}

$\begin{array}{rrr}188 & 2 & 1.1 \\ 184 & 13 & 7.1 \\ 161 & 28 & 17.4 \\ 578 & 137 & 23.7 \\ 455 & 120 & 26.4\end{array}$

a Victoria Schuck, "Femina Studens rei Publicae: Notes on Her Professional Achievement." PS, Fall, 1990, p. 625.

bPS, Summer, 1979 (article co-authored with Virginia Sapiro). One of the 22 section heads was female.

c'Three of the 16 section heads were women.

d This grand total included Program Committee, Organized Sections, and APSA Committee panels. Twelve of the 31 section persons heading sections organized by the Program Committee were women but only 3 of the 25 organizers of organized section panels were females.

1991 was the best year ever for women as participants. The major finding of my annual tallies is the significance of having women in a selection role. Where women headed sections or panels, there was a greater likelihood of other women being selected for program contributions. In 199111 of the 41 section persons were women $(26.8 \%)$. The sections they headed had women as $32.7 \%$ (34 of 104) of the chairpersons, $30.2 \%$ (149 of 494) of the paper givers, and $33.3 \%$ (46 of 138) of the discussants.

The convention sections led by 